\title{
The Effect of Tourism Towards the Food Security Issues to the Urban Poor in Sarawak, Malaysia: A Conceptual Approach
}

\author{
Muhammad Shahrin Hashim ${ }^{1}$, Azizan Mohamed Isa ${ }^{1}$, Ami Suhana Menon ${ }^{1} \&$ Norwani Mohd Nazari ${ }^{1}$ \\ ${ }^{1}$ Universiti Kuala Lumpur Business School, Universiti Kuala Lumpur, Malaysia \\ Correspondence: Muhammad Shahrin Hashim, Universiti Kuala Lumpur Business School, Universiti Kuala Lumpur, \\ Malaysia.
}

Received: April 30, 2019

Accepted: May 30, 2019

Online Published: June 11, 2019

doi:10.5430/ijfr.v10n5p241

URL: https://doi.org/10.5430/ijfr.v10n5p241

\begin{abstract}
The aim of this study is to study the effect of tourism towards the food security to the urban poor in Sarawak. This study applies mixed method approach with the adoption of Structural Equation Modelling using AMOS as the quantitative analytical tool. Both, practitioners and scholars can benefit from this study by having a better understanding of the current issues of food security towards the lower income margin people and how to resolve it.
\end{abstract}

Keywords: urban poor, food security, Malaysia, tourism, structural equation modelling

\section{Background}

With rapid economic growth and new technology have brought significant impact towards the accessibility towards healthy and nutritious food. A study by Himmelgreen, Romero Daza, Vega, Brenes Cambronero, \& Amador (2006) indicated that despite the increase in household income, food availability and health service, the rate of lifestyle related diseases such as coronary heart disease, hypertension, stroke and diabetes have been on the rise alongside with the rate of obesity to the economic growth of the respective developing countries (Ahmad, Zulaily, Shahril \& Abdullah, 2018).

The increase in diet-related, non-communicable, and other chronic diseases in the developing countries mainly caused by the migration of local food production to a more systematic international system of food commodities which includes consumption of energy-dense foods that are high in fat and low in complex carbohydrates, increased consumption of high saturated fat animal-derived foods, and reduced physical activity as a result of transportation modernisation, time-saving devices, and a more sedentary lifestyle (Himmelgreen et al., 2006; Xu \& Zhang 2018).

To keep up with the rapid development and urbanisation, Malaysia is heavily reliant on imports to feed the growing demand for food supplies. Despite efforts to be more self-sustainable, the demands are still growing. According to then Agriculture and Agro-Based Industry Minister Datuk Seri Ahmad Shabery Cheek said Malaysia's food import bill was RM45.39bil in 2016 (Martin Carvalho, Loshana K Shagar, Nicholas Cheng \& D Kanyakamuri). This amount had increased every year. The food security level in Malaysia ranks second among South-East Asian nations second behind Singapore in terms of food security and ahead of Thailand and Vietnam which are more advanced in agriculture (Martin Carvalho, 2018; Wonyra, 2018). In order to keep up with the demand, Malaysia has to result to engaging the international system of food commodities.

Malaysia has been consistently combating poverty since the post-independence in 1970s. The incidence of poverty has dropped from 52.4\% in 1970s to $15 \%$ in 1990s and 5.5\% in 2000 (Siwar, Ahmed, Bashawir, \& Mia, 2016; Zharikov, Bezpalov \& Ershova 2017). The rate of poverty has further decreased to 3.8\% in 2009 (Siwar et al., 2016; Samat, Elhadary, Hijles, Ghazali, \& Sirat, 2012; Sweis \& Sabri 2016). In 2016, it was reported that only $0.4 \%$ of the Malaysian population is living below the overall poverty line (Economic Planning Unit, 2018). It suggests that Malaysia has experienced a large reduction in the incidence of poverty during the last few decades, however with rapid development does put Malaysia on the statistics of lifestyle related diseases (Ismail et al., 2002; Mohamad Nor et al., 2018; Zafarullah, 2018). Malaysia is recorded as the highest number of obese rates in the South East Asia with prevalence of obesity was at 13.3 per cent, while overweight was at 38.5 per cent (Farezza hanum rashid, 2017; Wonyra, 2018).

Many previous studies focused on the trends and challenges of urban poor in Malaysia, comparable poverty between 
urban and rural, poverty alleviation and housing condition of the urban poor. However, there is lack of study on urban poverty in Malaysia, particularly assessing the impact of economic development such as tourism to the food security issues.

\section{Problem Statement}

Even Malaysia is facing a food security issue but Malaysia is also having a food wastage in the same time. As food tourist had increase every year, it also contributed to food waste. For example, according to the Consumers' Association of Penang (CAP) in The Star (2013), some 355,000kg of food was thrown away daily in Penang (Josephine Jalleh, 2017; Yusoff, et.al 2018). The amount of waste in Penang at increase in 2017 which had average of $700,000 \mathrm{~kg}$ food is wasted in the state daily (Nandini Balakrishnan, 2017). Food wasted had become an issue that may affect food security in Malaysia.

Food security issues become more critical when the cost to consume the food is higher than before. Human being needs food for survival. When the cost is too high, people may face difficulties to obtain healthy and good quality of food. Food insecurity is a common problem among the low-income households. With the increasing of tourist arrival today, current food security issues can become an important issue to deal with not only by governments but also food supplier and food provider. Thus, it is essential to ensure the food security is achieved at the highest level. If the food security issues are not well managed, the one who will get the biggest impact is urban poor (Tanoos, 2017; Taneri, 2018). Therefore, the key challenge for food security in the country is to achieve self-sufficiency level in most of the food requirements as well as to reduce dependency on food importation. So, further research is urgently needed to set more effective policies and strategies for achieving the self- sufficiency in producing food commodities in the country.

\section{Research Question}

The following three questions will form the basis and core of this research:

1. What is food consumption pattern among urban poor?

2. Where are the food sources come from?

3. How Food Tourism would give an impact on food sources to the Urban Poor?

\section{Literature Reviews}

\subsection{Tourism in Malaysia}

Malaysia had become one of the world's leading tourist destination with an increase in tourist arrival year by year. Tourist arrival to Malaysia in 2016 registered a hike of $4.0 \%$ compared to the same period in 2015 . The country received 26.8 million tourists compared to 25.95 million tourists in 2017 (Tourism Malaysia, 2018). Statistics also shows that more tourists travel to Malaysia for reasons other than leisure.

In a study by Alam, Er, Begum, \& Alam, (2015) indicated that among of the factors that attract tourists to come to Malacca are the cultural and ethnic diversity which are usually translated in the form of cultural activities and food diversity. Malacca is one of the states that is known for having food diversity in which carries the branding of 'food paradise' or food tourism in Malaysia alongside Penang and Kuala Lumpur (Tourism Malaysia, 2018). Food tourism has contributed an increase in the expenditure on food and beverage from 8.180 million in 2013 compare to 10.927 million in 2017 (Tourism Malaysia, 2018).

According to the Minister of Tourism, Arts, Culture, Youth and Sports Datuk Abdul Karim Rahman Hamzah, the Tourism ministry was actively embarked on the activities and promotion towards the campaign 'Visit Sarawak 2019' at the end of 2018. The choice of Sarawak as for 2019 campaign is to make Sarawak as the premier tourist destination of choice due to its extensive cultural diversity, old heritage tourists spots, nature and wildlife preservation (The Borneo Post, 2018). A total of 4.85 million visitors came to Sarawak last year - an increase of 4.2 per cent compared to 2016 - bringing in an estimated tourist receipt of RM8.59 billion. He attributed the rise was also contributed by the creation of the Kuching-Shenzhen direct flight path which commenced in December last year (The Borneo Post, 2018).

\subsection{Urban Poor in Malaysia}

Urban poverty is a dynamic condition of vulnerability among the urban dwellers caused by rapid urbanization and modernisation (Siwar et al., 2016; Yang, 2018). A study by Yusoff (2013) identified the vulnerable groups in urban areas of the country. The urban vulnerable groups are; Low to income earner whose monthly income is, on average, 
MYR 2,334; People with low educational level and engaged in low skill and less productive sector; Handicapped; Single parent; Youth; Orang asli; Minority Sabah and Sarawak; Estate workers; and Elderly.

The numbers of urban vulnerable people are higher at Selangor, Johor, Perak, Sabah, Sarawak and Kedah as in more developed states of the country. It was also reported that majority $(63 \%)$ of urban vulnerable group are Bumiputera. A comparatively higher portion (66.1\%) of household heads is above 40 years old (Siwar et al., 2016; Yusoff, 2013).

There had been widely debated on the definition of poverty which clearly the issue is far more multidimensional and complex. Income and consumption had been the earlier measure of level of poverty however according to Zainal, Kaur, Ahmad, \& Khalili (2012), income and consumption do not capture the reality dimension of being in poverty such as the lack of comfort, health, personal safety, and social inclusion.

As the World Bank defines poverty as failure in income "dollar-a-day", Malaysia has developed a poverty line income as a guideline to measure the level of poverty as part of the effort to eradicate poverty. This poverty line was applied for the evaluation of the minimum consumption on moderate sized household demands which includes food, shelter, clothing and others. Therefore, for per household income that is below the poverty income line, then it is described as living in poverty (Islam, Ghani, Abidin, \& Rayaiappan, 2017; Yamaguchi, 2018). The contributing factors to poverty are usually associated with low levels of education, lack of employment opportunities, large family size, and poor housing conditions. With an escalating cost of living in urban areas, the urban poor are very vulnerable to uncertainties in income (Zainal et al., 2012).

Poverty line income is RM960 for Peninsular Malaysia, RM1,180 for Sabah \& WP Labuan and RM1020 for Sarawak (Economic Planning Unit, 2018)

Few past studies have showed the significant relationship between social economic statuses with food consumption behaviour. A study by Hui Tee, Gan, Tan, \& Chin (2018) indicated that in the household whereby the maternal and paternal are both working to sustain the household expenses would not be particularly concern with the supply of nutritious food. Furthermore, the study by Hui Tee et al (2018) also the education level of maternal does have a contributing effect on the quality of food consumptions however paternal are only concern with the family bonding and being main breadwinner of the family which is supported by a study by (Ahmad, Zulaily, Shahril \& Abdullah, 2018). In the study by (Ahmad, Zulaily, Shahril \& Abdullah, 2018) also indicated that higher household income and smaller household sizes has direct effect with the socio economic status of the household with the possession of higher purchasing power and food affordability. The social economic status has the connection with the level of parental education.

\subsection{Food Security}

Food security is referred as successfully attainable "when all people at all times have access to sufficient, safe, nutritious food to maintain a healthy and active life" (World Health Organization (WHO), 2015). In the same context, according to USDA Economic Research, the highest level of food security is achieved when households have no problem or anxiety about consistently accessing sufficient food. It is regarded as complex sustainable development issue and problems associated to economic development, the environment and health (World Health Organization (WHO), 2015).

Food security includes the following dimensions:

- $\quad$ availability: the availability of sufficient quantities of appropriate quality;

- $\quad$ access: access by individuals to adequate resources for acquiring appropriate foods for a nutritious diet on a regular basis;

- utilization: utilization of food through adequate diet, clean water, sanitation and health care to reach a nutritional well-being where all physiological needs are met;

- $\quad$ stability: a population, household or individual must have access to food at all times and should not risk losing access as a consequence of sudden shocks or cyclical events.

Problems with any of these dimensions can lead to food insecurity, which define as "a household-level economic and social condition of limited or uncertain access to adequate food," (USDA). It is considered as an important national health problem and an under recognized social determinant of health (Network, F. F., \& Assistance, M. S. N., 2016)

\subsection{Food Consumption in Tourism}

Based on the previous literature of food consumption in tourism: it is largely essential (tourists need to eat when they travel away from home, unless they bring home food to the destination), it occurs in a foreign and unfamiliar 
contexts (in terms of food and foodways), it is of a temporal nature (tourists are usually in a sojourn instead of staying in the destination for a prolonged period of time), and it bears symbolic meaning and can be associated with travel motivation (Chang et al., 2010; Cohen \& Avieli, 2004).

\subsection{Food Security and Tourism}

The issue of food security is gaining momentum around the world, predominantly in Malaysia. Malaysia has achieved a significant increase in the production of several basic food items such as rice, fruits, vegetables, fisheries, and poultry. However, the country is highly dependent on importation of many agricultural products such as wheat, beef, mutton and dairy items due to their rising demand as well as relatively limited local production (Ahmed, F., \& Siwar, C., 2013).

In Malaysia, the food consumption is at a considerable level. As of 2016, food consumption pattern in Malaysia indicated $1500 \mathrm{kcal} / \mathrm{day}$. At the same time, the tourism sector in the region is increasing rapidly. According to Tourism Malaysia, the country received 26.8 million tourists compared to 25.95 million tourists in 2017. Hence, this increase in tourists visiting the region would obviously lead to parallel growth in its hospitality sector which entail the growth of the food and beverage sector as well. The number of tourists, population growth, rising disposable income levels, and changing consumption patterns are among the key factors affecting the increase of food consumption. (Malek, 2014; Napier, 2014),

Food, like other factors, such as accommodation, transportation and attraction are a fundamental element of the tourist product (Reynold, 1994). The term "food tourism" is defined as visitation to primary and secondary food producers, food festivals, restaurants and specific locations for which food tasting and/or experiencing the attributes of specialist food production regions and is the primary motivation for travel (Mitchell \& Hall, 2001). Previously, people travel and they need food to eat but nowadays the need has changed whereby people are willing to travel because of food. This phenomenon is giving a good impact toward the growth of economic in Malaysia and opens a huge opportunity for people to contribute either directly or not to the industry.

\section{Methodology}

The objective for this Research is to explore the effect of food tourism towards the security of food to the urban poor in Kuching, Sarawak. This Research will explore whether tourism in Kuching, Sarawak has any adverse impact to the urban poor food consumption pattern in Kuching.

Qualitative research begins with the assumptions, a worldview, possibility using theoretical lens, and to study the research problems that have an impact to certain group of people (Creswell, 2007). The key word here is that qualitative research is being used to make sense and interpret the phenomena that have an impact to a set of people (Denzin \& Lincoln, 2011). When researcher embarks on qualitative research, the researcher is interested to investigate how human arrange themselves in reaction to their surrounding through symbols, rituals, social structures, social roles, and other reactions (Berg \& Lune, 2011).

Recent studies show that there is trend of researchers combining qualitative and quantitative approaches. This combination is known as mixed-method research. In research that involve two kinds of causes; intentional and natural, it was suggested that intentional causation is related to qualitative approach and natural causation is related to quantitative approach (Howe, 2011).

Based on the above, the objective of this Research will be examined through mixed-method research.

The Researcher proposes to conduct cross-sectional study in two parts of Kuching city; namely the Kuching Waterfront area and Damai area (Research Areas). Both areas are known by tourism activities in Kuching. Researcher will conduct community presentation on the purpose and scope of the study. The Research will also use local research assistant, local maps to cover all sections of the Research Areas and to recruit Respondents.

The sample size of the sample must be broad to assess the characteristic of the population adequately to reflect realistic outcomes. Saunders, Lewis \& Thornhill (2012) gives a guiding principle for sample size as per Schedule below. 
Table 1. Sample size for different sizes of population at a $95 \%$ confidence level

\begin{tabular}{lllll}
\hline & $\begin{array}{l}\text { Margin of error } \\
\mathbf{( 5 \% )}\end{array}$ & $\begin{array}{l}\text { Margin of error } \\
\mathbf{( 3 \% )}\end{array}$ & $\begin{array}{l}\text { Margin of error } \\
\mathbf{( 2 \% )}\end{array}$ & $\begin{array}{l}\text { Margin of Error } \\
\mathbf{( 1 \% )}\end{array}$ \\
\hline Population (N) & Sample Size (s) & sample size (s) & Sample size (s) & Sample size (s) \\
\hline 1000 & 278 & 516 & 706 & 906 \\
\hline 2000 & 322 & 696 & 1091 & 1655 \\
\hline 5000 & 357 & 879 & 1622 & 3288 \\
\hline 10000 & 370 & 964 & 1936 & 4899 \\
\hline 100000 & 384 & 1066 & 2395 & 9513 \\
\hline 1000000 & 384 & 1067 & 2400 & 9595 \\
\hline
\end{tabular}

Source: Saunders, Lewis \& Thornhill (2012)

Sampling frame can be defined as the listing of all units in the population from which the sample are being selected (Bryman \& Bell, 2011). A good sample design is that it can accurately and precisely represents the characteristic of the population (Cooper \& Schindler, 2011). This Research will use data from Statistic Department to have a complete and updated sampling frame. This research requires as sample of all Kuching residents.

Sample can be defined as a subset of the population available for selection in the process of sampling or a sub collection picked from the population of a research. Sample represents a segment out of a total population, which is selected from the population (Bryman \& Bell, 2011). We used sample because the cost is lower and data can be collected in short time (Cooper \& Schindler, 2011)

This Research will use a simple random sampling technique to enable the Researcher to generalise the whole population of Kuching residents (Bryman \& Bell, 2011). In simple random sampling each individual in population has the same chance of being selected (Cooper \& Schindler, 2011).

Based on Bryman \& Bell (2011), the Researcher is proposing the following steps:

(a) Define the population. The Researcher had identified that the Respondents will be residents living at the Research Areas; and

(b) Decide the sample size of this Research.

According to the Sarawak Tourism website, the total population in Kuching is 650,000. Based on Saunders et al (2012) sample determination table, the Researcher proposed to hand over survey questions to 384 Respondents would be sufficient for this Research. The survey will cover questions on household economics and demographics, food security, and maternal-child anthropometry and dietary intake.

In addition, the Researcher proposes for open-ended interviews on access to food, lifestyle changes in diet and physical activities. In qualitative research, determination of number of samples is not straightforward. The aim of this Research is to use smaller sample size to collect more intense and deeper collection of data to find homogeneity of the sample (Padget, 2008). Previous studies show that number of respondents from 15 to 30 per target group is an acceptable number (Guest, Namey, \& Mitchell, 2013). For the purpose of this Research, the Researcher propose of 30 Respondents would be sufficient to provide a representative or average view of the Respondents.

The findings from the open-ended interview will be reported in order to explain patterns reflected in the quantitative data.

\subsection{Measuring Food Insecurity}

To measure food insecurity, the Reseacher is proposing Radimer/Cornell Scale, which was developed to reflect the perspective of actual experience hunger and food insecurity (Radimer, Olson, Greene, Campbell, \& Habicht, 1990). In this Research, we will use this scale to urban poor at the Research Area. The Radimer/Cornell Scale has been successfully used another research on low-income Latinos (Himmelgreen, et al., 2000).

Radimer/Cornell Scale of food insecurity managed a process with a general sequence as the problem of food insecurity become worse. The first experience is household food insecurity, followed by compromises in the quality and quantity of consumption of the adults. The last stage is decrease in the quantity of food eaten by children 
(Kendall et al. 1996).

Hence, based on the response from the Respondents at the Research Area, the Researcher will use 10 items of Radimer/Cornell scale to classify the Respondents into mutual exclusive groups that reflects their increasingly severe food sufficiency problems.

Radimer/Cornell Hunger and Food Insecurity Item

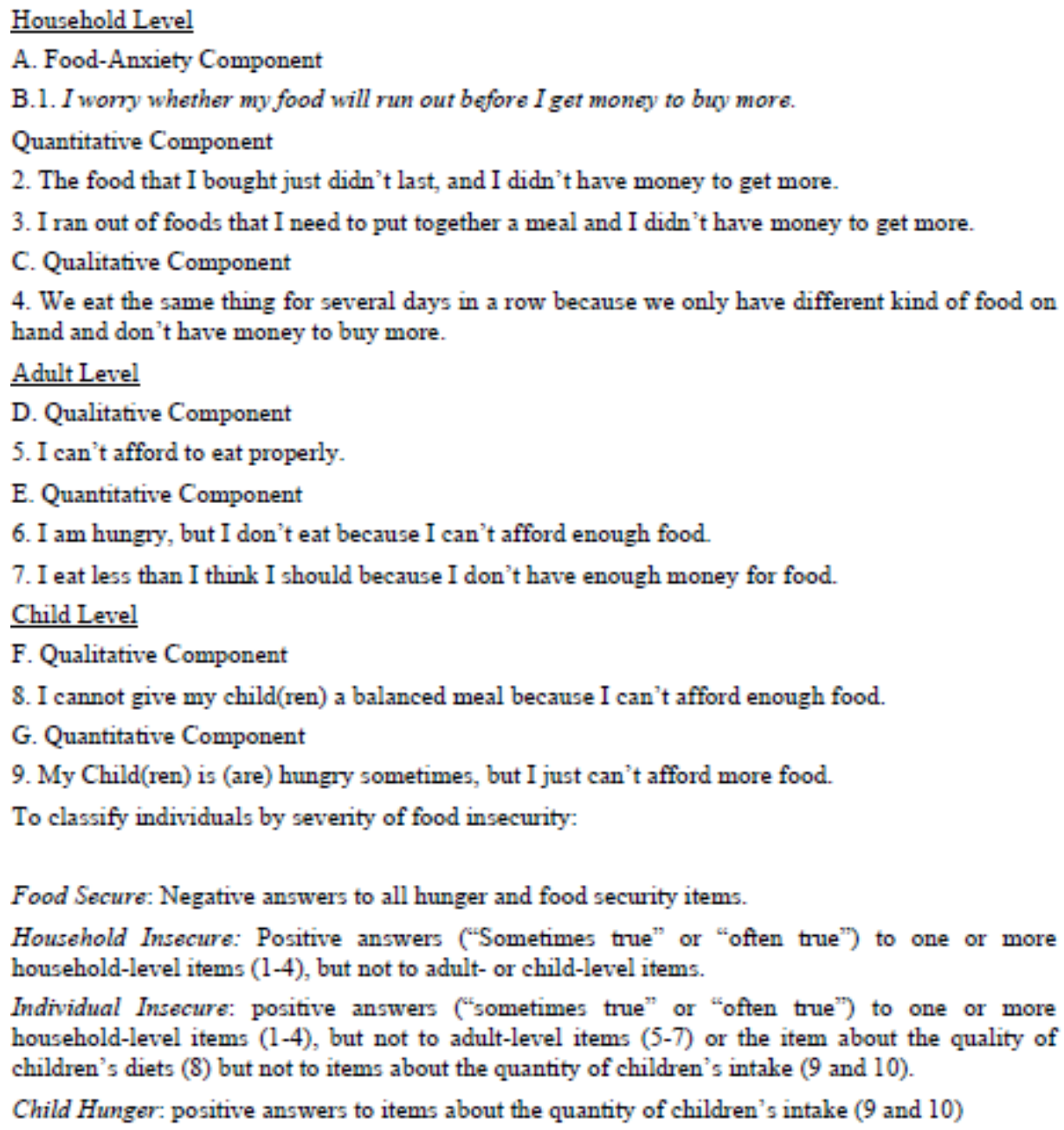

Source: Kendall et al. (1996)

Response categories from item 1 through 10 are "not true", "Sometimes true" or "often true"

Radimer/Cornell scale is used because it can identify problems connected with lack of sufficient food and also the issue pertaining to the quality of the diet of the Respondent (Himmelgreen, Cambronero, \& Amador, 2006).

\subsection{Analysis of Quantitative Data}

The study of the urban poor and their households will be divided into two groups as follows: 


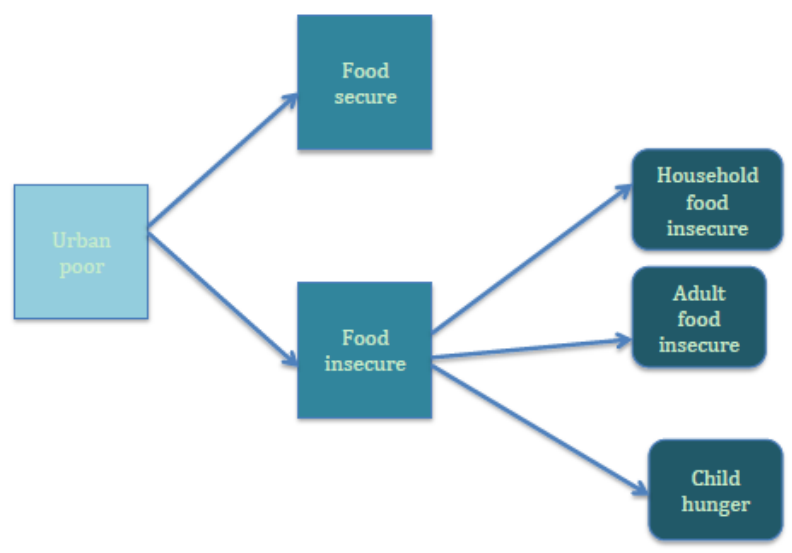

Figure 1. The grouping for respondents

In addition, the three sub-groups under food insecurity will be combined to form collapsed food insecurity group. The Researcher is proposing the following theoretical design:

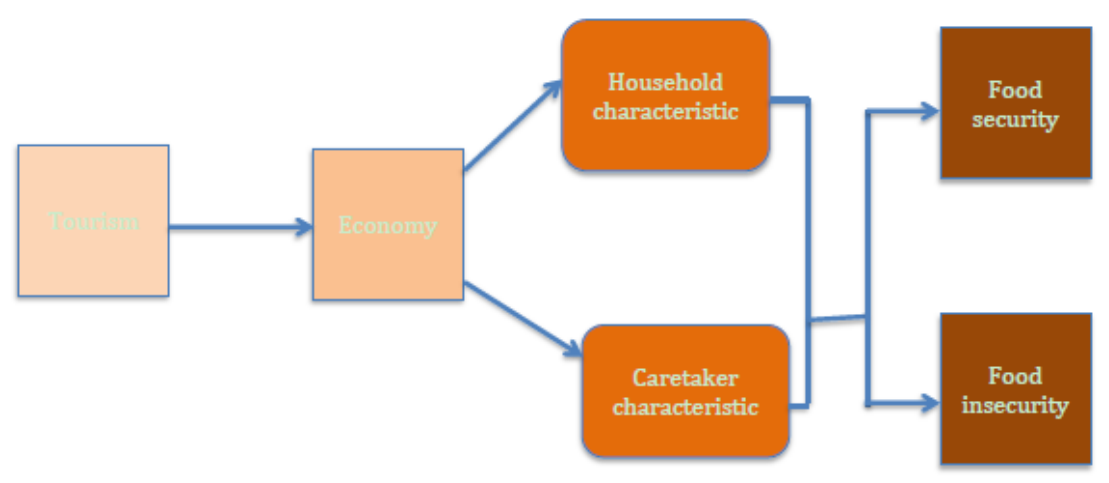

Figure 2. Proposed theoretical design

\subsection{Analysis of Qualitative Data}

The narrative of data derived from open-ended interviews will be translated into English and entered onto Microsoft Office words to look for recurring words and phrases. The Researcher will then use the results to categorize the Respondents response into themes.

This study will examine several predictors through the Structural Equation Modelling using AMOS. The analysis will include the exploratory factor analysis, reliability analysis and confirmatory factor analysis will be used to test for construct validity, reliability, and measurements loading. Statistical Package for Social Science (SPSS) will be used to analyse the preliminary data and provide a descriptive analysis of the sample such as means, standard deviations and frequencies.

\section{Conclusion}

As a conceptual paper, this study is limited to literature and prior empirical research. The study provides valuable insights for scholars and practitioners on better understanding of the food security issues by the Urban poor. Future studies can replicate the current study's model to be applied in different countries.

\section{References}

Ahmad, A., Zulaily, N., Shahril, M. R., Abdullah, E. F. H. S., \& Abdullah, A. A. (2018). Association between socioeconomic status and obesity among 12-year-old Malaysian adolescents. PLoS ONE. 
https://doi.org10.1371/journal.pone.0200577

Ahmed, F., \& Siwar, C. (2013). Food security status, issues and challenges in Malaysia: A review. Journal of Food, Agriculture and Environment, 11(2), 219-223.

Alam, A. S. A. F., Er, A. C., Begum, H., \& Alam, M. M. (2015, July). The Factors of Selecting Malaysia as Tourist Destination. Mediterranean Journal of Social Sciences. https://doi.org/10.5901/mjss.2015.v6n3s1p491

Balakrishnan, N. (2017). People In Penang Throw Away 700,000KG Of Food Every Day. Retrieved 22 January 2019, from https://says.com/my/news/penangites-waste-700-000kg-of-food-daily

Berg, B., \& Lune, H. (2011). Qualitative research methods for the social sciences (8th ed., p. 8). Boston, MA: Pearson.

Carvalho, M. (2018). Malaysia's food security ranks No. 2 in South-East Asia. Retrieved 22 January 2019, from https://www.thestar.com.my/news/nation/2018/07/26/malaysia-food-security-ranks-no2-in-south-east-asia/

Carvalho, M., Shagar, L. K., Cheng, N., \& Kanyakumari, D. (2016). RM45bil for food import bill. Retrieved 22 January 2019, from https://www.thestar.com.my/news/nation/2016/03/15/rm45bil-for-food-import-bill-amount-is-rm18bil-higher-th an-export-tag-says-shabery/\#w8mVsy5Cjrq7zYju.99

Chang, R. C. Y., Kivela, J., \& Mak, A. H. N. (2010). Food preferences of Chinese tourists. Annals of Tourism Research, 37(4), 989-1011. https://doi.org/10.1016/j.annals.2010.03.007

Cohen, E., \& Avieli, N. (2004). Food in tourism: Attraction and impediment. Annals of Tourism Research, 31(4), 755-778. https://doi.org/10.1016/j.annals.2004.02.003

Creswell, J. (2007). Qualitative inquiry and research design: choosing among five approaches (p37). Thousand Oaks, CA: SAGE.

Denzin, N., \& Lincoln, Y. (Eds). (2011). The SAGE handbook of qualitative research (4th ed., p. 3). Thousand Oaks, CA: SAGE.

Economic Planning Unit. (2018). The Malaysian Economy in Figures 2018. Ministry of Economic Affairs. Retrieved from http://www.bnm.gov.my/files/publication/ar/en/2017/ar2017_book.pdf

Guest, G., Namey, E. E., \& Mitchell, M. L. (2013). Collecting qualitative data: A field manual for applied research (pp. 62-63). SAGE. https://doi.org/10.4135/9781506374680

Himmelgreen, D. A., Romero Daza, N., Vega, M., Brenes Cambronero, H., \& Amador, E. (2006). "The tourist season goes down but not the prices." Tourism and food insecurity in rural Costa Rica. Ecology of Food and Nutrition, 45(4), 295-321. https://doi.org/10.1080/03670240600848753

Howe, K. (2011). Mixed methods, mixed cause?. Qualitative inquiry, 17(2), 166-171. https://doi.org/10.1177/1077800410392524

Hui Tee, J. Y., Gan, W. Y., Tan, K. A., \& Chin, Y. S. (2018). Obesity and unhealthy lifestyle associated with poor executive function among Malaysian adolescents. PLoS ONE, 13(4), 1-17. https://doi.org/10.1371/journal.pone.0195934

Islam, R., Ghani, A. B. A., Abidin, I. Z., \& Rayaiappan, J. M. (2017). Impact on poverty and income inequality in Malaysia's economic growth. Problems and Perspectives in Management, 15(1), 55-62. https://doi.org/10.21511/ppm.15(1).2017.05

Ismail, M. N., Chee, S. S., Nawawi, H., Yusoff, K., Lim, T. O., \& James, W. P. T. (2002). Obesity in Malaysia. Obesity Reviews, 3(3), 203-208. https://doi.org/10.1046/j.1467-789X.2002.00074.X

Jaleh, J. (2013). CAP: 355,000kg of food goes to waste daily in Penang. Retrieved 22 January 2019, from https://www.thestar.com.my/news/nation/2013/06/04/cap-355000kg-of-food-goes-to-waste-daily-in-penang/\#1 QKi6YgM9g06qAWJ.99

Lichtman, M. (2014). Qualitative research for the social sciences (p. 7). SAGE publications.

Malek, C. (2014). Growing population will force UAE to face up to food security TheNational. Retrieved 31 August 2015, from http://www.thenational.ae/uae/grow ing-population-will-force-uae-to-face-up-to-food-security

Mitchell, R., \& Hall, C. (2003). Consuming tourists: food tourism consumer behaviour. In Hall, C., Sharples, L., Mitchell, R., Macionis, N., \& Cambourne, B. (Eds.), Food Tourism Around the World: Development, Management and Markets, Butter-worth-Heinemann (pp. 64-84). Oxford.

Mohamad Nor, N. S., Ambak, R., Mohd Zaki, N., Abdul Aziz, N. S., Cheong, S. M., Abd Razak, M. A., ... Aris, T. 
(2018). An update on obesity research pattern among adults in Malaysia: A scoping review. BMC Women's Health, 18(Suppl 1). https://doi.org/10.1186/s12905-018-0590-4

Napier, M. (2014). Capitalising On The Middle East's Rising Food Demand GulfBus. Retrieved 31 August 2015, from http://gulfbusiness.com/2014/10/capitalising-mid dle-easts-rising-food-demand/

Network, F. F., \& Assistance, M. S. N. (2016). Food insecurity: a public health issue. Public Health Reports, 131(5), 655-657. https://doi.org/10.1177/0033354916664154

Padgett, D. (2008). Qualitative methods in social work research (2nd ed., p. 56). Thousand Oak, CA: SAGE.

Rashid, F. H. (2017). Malaysians most obese in region. The New Straits Times. Retrieved from https://www.nst.com.my/news/nation/2017/06/246538/malaysians-most-obese-region

Reynolds, P. C. (1994). Culinary heritage in the face of tourism. In Cooper \& Lockwood (Eds.), Progress in Tourism, Recreation and Hospitality Management (Vol. 6, pp. 189-194). London: Belhaven Press.

Samat, N., Elhadary, Y. A. E., Hijles, F. M., Ghazali, S., \& Sirat, M. (2012). Poverty and Deprivation: Using Geographic Information System in Evaluating The Accessibility of Households to Food Retailers in Penang State, Malaysia. Journal of Social Science and Humanities, 7(2), 15. Retrieved from http://journalarticle.ukm.my/5639/1/narimah012.pdf

Siwar, C., Ahmed, F., Bashawir, A., \& Mia, M. S. (2016). Urbanization and Urban Poverty in Malaysia: Consequences and Vulnerability. Journal of Applied Sciences, 16(4), 154-160. https://doi.org/10.3923/jas.2016.154.160

Sweis, K. M. H., \& Sabri, T. B. H. (2016). The Effect of Public Debt on Domestic Product and Unemployment (An Empirical Study on the Palestinian Economy). International Journal of Business, Economics and Management, 3(10), 133-143. https://doi.org/10.18488/journal.62/2016.3.10/62.10.133.143

Taneri, A. (2018). Scenario-Based Case Study Method and the Functionality of the Section Called" From Production to Consumption" from the Perspective of Primary School Students. Asian Journal of Education and Training, 4(1), 56-61. https://doi.org/10.20448/journal.522.2018.41.56.61

Tanoos, J. J. (2017). East Asian trade cooperation versus US and EU protectionist trends and their association to Chinese steel exports. Asian Journal of Economics and Empirical Research, 4(1), 1-7.

The Borneo Post. (2018). Higher visitor arrivals in 2017, over RM8 billion earned. Retrieved from http://www.theborneopost.com/2018/07/17/higher-visitor-arrivals-in-2017-over-rm8-billion-earned-minister/

Tourism Malaysia. (2018). Retrieved from http://www.tourism.gov.my.statistic

Wonyra, K. O. (2018). Impact of Telecommunications Market Liberalization on Labor Productivity in Economic Community of West African States. Journal of Social Economics Research, 5(2), 63-74.

Wonyra, K. O. (2018). Industrialization and Economic Growth in Sub-Saharan Africa: The Role of Human Capital in Structural Transformation. Journal of Empirical Studies, 5(1), 45-54.

Xu, Q., \& Zhang, H. (2018). Optimal Bid Strategies in Crowdsourcing Contest Based on Multi-Attribute Auctions. International Journal of Emerging Trends in Social Sciences, 4(2), 67-74.

Yamaguchi, M. (2018). Are Foreign Banks in China Homogenous?: Classification of their Business Patterns. Journal of Accounting, Business and Finance Research, 3(1), 10-17. https://doi.org/10.20448/2002.31.10.17

Yang, D. C. (2018). Methods Used by Fourth Graders when Responding to Number Sense-Related Questions. American Journal of Education and Learning, 3(2), 1-13. https://doi.org/10.20448/804.3.1.1.13

Yusoff, H., Baba, J., Ariffin, S., \& Embong, R. (2018). Quality Academics in Higher Education: Mapping the Key Components. International Journal of Asian Social Science, 8(11), 948-957.

Yusoff, R. B. (2013). Urban development challenges in the Malaysian context. In Proceedings of the Conference on Regional Urban Policy Exchange.

Zafarullah, M. (2018). Impact of VAT on UAE Economy. Asian Development Policy Review, 6(1), 41-49.

Zainal, N. R., Kaur, G., Ahmad, N. A., \& Khalili, J. M. (2012, July). Housing Conditions and Quality of Life of the Urban Poor in Malaysia. Procedia - Social and Behavioral Sciences, 50, 827-838. https://doi.org/10.1016/j.sbspro.2012.08.085

Zharikov, V. V., Bezpalov, V. V., \& Ershova, M. V. (2017). Modern Conditions of Development of Leasing Market in Russia on the Example of Rail Transport. Asian Journal of Economic Modelling, 5(1), 1-10. 